\title{
Pengaruh Model Pembelajaran Inkuiri Terbimbing Berbantuan Media Benda Konkret Terhadap Sikap Ilmiah dan Hasil Belajar IPA
}

\author{
Ni Made Ayu Suryantari ${ }^{1,}$ Ketut Pudjawan², I Made Citra Wibawa ${ }^{3}$
}

${ }^{12}$ Jurusan Pendidikan Guru Sekolah Dasar, ${ }^{2} J u r u s a n$ Teknologi Pendidikan Universitas Pendidikan Ganesha, Indonesia

\section{A R T I CLEINFO \\ Article history: \\ Received 18 May 2019 \\ Received in revised form 30 June 2019 \\ Accepted 15 July 2019 \\ Available online 25 August 2019 \\ Kata Kunci: \\ Inkuiri terbimbing, media \\ benda konkret, sikap ilmiah, \\ hasil belajar. \\ Keywords: \\ Guided inquiry, concrete \\ media, scientific \\ ettitude,learning outcomes}

\begin{abstract}
A B S T R A K
Penelitian ini bertujuan untuk mengetahui pengaruh yang signifikan model pembelajaran inkuiri terbimbing berbantuan media benda konkret terhadap sikap ilmiah dan hasil belajar IPA siswa. Jenis penelitian ini adalah penelitian eksperimen semu dengan desain non equivalenpost-test only control group design. Populasi dalam penelitian ini adalah seluruh siswa kelas V SD Gugus IV Kecamatan Buleleng Tahun Pelajaran 2017/2018 berjumlah 155 orang.Sampel penelitian ini diambil dengan teknik clusterrandom sampling. Sampel penelitian ini yaitu siswa kelas V SD N 3 Penglatan yang berjumlah 23 orang dan siswa kelas V SD N 3 Alasangker yang berjumlah 20 orang.Data sikap ilmiah dikumpulkan dengan metode non tes menggunakan instrumen kuisioner sikap ilmiah dan data hasil belajar IPA dikumpulkan dengan metode tes menggunakan tes pilihan ganda. Data yang dikumpulkan, dianalisis menggunakan statistis deskriptif dan Manova. Hasil penelitian menunjukkan: (1) terdapat perbedaan yang signifikan sikap ilmiah
\end{abstract} antarasiswa yang mengikuti model pembelajaran inkuiri terbimbing berbantuan media benda konkret dengan pembelajaran konvensional $\left(F_{\text {hitung }}=25,88>F_{\text {tabel }}=4,08\right)$, (2) terdapat perbedaanyang signifikan hasil belajar IPA antarasiswa yang mengikuti model pembelajaran inkuiri terbimbing berbantuan media benda konkret dengan pembelajaran konvensional $\left(F_{\text {hitung }}=15,16>F_{\text {tabel }}=4,08\right)$, dan (3) secara bersama-sama,terdapat perbedaan yang signifikan sikap ilmiah dan hasil belajar IPA antara siswa yang mengikuti model inkuiri terbimbing berbantuan media benda konkret dengan pembelajaran konvensional $(\mathrm{F}=15,111 ; \quad \mathrm{p}<0,05)$. Hal ini menunjukkan pembelajaran menggunakan model pembelajaran inkuiri terbimbing berbantuan media benda konkret berpengaruh positif terhadap sikap ilmiah dan hasil belajar IPA siswa.

\section{A B S T R A C T}

This research aimed to investigate the significant effect of guided inquiry learning model that assisted by concrete media on scienctific ettitude and science learning outcomes. The type of this research was quasi experiment research, using non equivalen posttest only control group design. The population in this research is all students at the fifth grade of SD cluster IV Buleleng District in academic years 2017/2018 are 155 students. The sample was taken by random sampling techniques. The sample of the research are 23 students of fifth grade of SDN 3 Penglatan and 20 students of fifth grade of SDN 3 Alasangker. Scientific attitude data collected by non test method using scienctific attitude questionnaire and science learning outcomes collected by test method using multiple choice test. The collected data analyzed using descriptive statistic analysis and Manova. The result showed that: (1)there was significant differences of scienctific ettitude between student who are following guided inquiry learning model that assisted by concrete mediawith conventional learning $\left(F_{\text {hitung }}=25,88>F_{\text {tabel }}=4,08\right)$, (2) there was significantdifferences of science learning outcomes between student who are following guided inquiry learning model that assisted by concrete media with conventional learning $\left(F_{\text {hitung }}=15,16>F_{\text {tabel }}=4,08\right)$, and (3)simultaneously, there was significant differences of scientific attitude and science learning outcomes between student who are following guided inquiry learning model that assisted by concrete media with conventional learning(sig. $=0,000<0,05)$. This means that the learning using guided inquiry learning model that assisted by concrete media had positive effect on scienctific ettitude and science learning outcomes.

Copyright (C) Universitas Pendidikan Ganesha. All rights reserved.

\footnotetext{
${ }^{1}$ Corresponding author.

E-mail addresses: suryantari.ayu@yahoo.com (Ni Made Ayu Suryantari)
} 


\section{Pendahuluan}

Pendidikan merupakan sebuah sistem. Sebagai sistem, aktivitas pendidikan terbangun dalam beberapa komponen, yaitu pendidik, peserta didik, tujuan pendidikan, alat pendidikan, dan lingkungan pendidikan. Semua komponen yang membangun sistem pendidikan, saling berhubungan, saling tergantung, dan saling menentukan satu sama lain. Setiap komponen memiliki fungsi masing-masing dalam rangka mencapai tujuan pendidikan. Aktivitas pendidikan akan terselenggara dengan baik apabila didukung oleh komponen-komponen dimaksud. Fungsi pendidikan sebenarnya adalah menyediakan fasilitas yang dapat memungkinkan tugas pendidikan dapat berjalan lancar, baik secara struktural, maupun secara institusional. Secara struktural menuntut terwujudnya struktur organisasi yang mengatur jalannya proses kependidikan. Secara institusional mengandung implikasi bahwa proses kependidikan yang terjadi dalam struktur organisasi itu dilembagakan untuk lebih menjamin proses pendidikan itu berjalan secara konsisten dan berkesinambungan mengikuti kebutuhan dan perkembangan manusia yang cenderung ke arah tingkat kemampuan yang optimal (Saat, 2015).

Pasal 1 UU SISDIKNAS no. 20 tahun 2003 disebutkan bahwa Sistem Pendidikan Nasional adalah keseluruhan komponen pendidikan yang saling terkait secara terpadu untuk mencapai tujuan pendidikan nasional. Berangkat dari bunyi pasal ini dapat diketahui bahwa pendidikan adalah sistem yang merupakan suatu totalitas struktur yang terdiri dari komponen yang saling terkait dan secara bersama menuju kepada tercapainya tujuan (Soetarno, 2003: 2). Adapun komponen-komponen dalam pendidikan nasional antara lain adalah lingkungan, sarana-prasarana, sumberdaya, dan masyarakat. Komponen-komponen tersebut bekerja secara bersama-sama, saling terkait dan mendukung dalam mencapai tujuan pendidikan. Tujuan pendidikan nasional yang dirumuskan dalam UU SISDIKNAS adalah untuk mengembangkan potensi anak didik agar menjadi manusia yang beriman dan bertakwa kepada Tuhan Yang Maha Esa, berakhlak mulia, sehat, berilmu, cakap, kreatif, mandiri, dan menjadi warga Negara yang demokratis serta bertanggung jawab (Munirah, 2015).

Kualitas sumber daya manusia memegang peranan penting dalam proses keberhasilan pembangunan suatu bangsa dan negara. Salah satu upaya yang dapat dilakukan untuk meningkatkan kualitas sumber daya manusia adalah dengan meningkatkan kualitas pendidikan. Menurut Undangundang Republik Indonesia Nomor 20 Tahun 2003 tentang Sistem Pendidikan Nasional, Bab 1 Pasal 1 menyatakan, pendidikan adalah usaha sadar dan terencana untuk mewujudkan suasana belajar dan proses pembelajaran agar siswa secara aktif mengembangkan potensi dirinya untuk memiliki kekuatan spiritual keagamaan, pengendalian diri, kepribadian, kecerdasan, akhlak mulia, serta keterampilan yang diperlukan dirinya, masyarakat, bangsa, dan negara.

Pendidikan tidak hanya menekankan pada pengetahuan saja, tetapi juga menekankan pada pembentukan sikap dan karakter siswa. Sehingga dalam menyelenggarakan pendidikan harus sesuai dengan tujuan pendidikan nasional. Berdasakan tujuan pendidikan, pendidikan tidak hanya memberikan pengetahuan dan keterampilan tetapi diharapkan nantinya membantu siswa untuk mengembangkan potensi diri yang dimiliki. Pengembangan potensi diri diharapkan dapat memunculkan generasi muda yang unggul dalam bidangnya dan dapat hidup bermasyarakat, berbangsa, dan bernegara.

Tingkat perkembangan suatu bangsa juga ditentukan oleh unsur-unsur kemajuan dan perkembangan suatu pendidikan. Unsur-unsur itu berupa guru, siswa, sarana dan prasarana pendidikan, maupun kebijakan yang telah ditetapkan pemerintah dalam bidang pendidikan. Berbagai upaya dilakukan pemerintah Indonesia untuk meningkatkan kualitas pendidikan, mulai dari pembaharuan kurikulum, peningkatan sarana prasarana, sampai pada peningkatan mutu pendidik sebagai tenaga profesional. Guru menjadi salah satu faktor penentu keberhasilan pendidikan di Indonesia. Berdasarkan Undang-undang Republik Indonesia Nomor 14 Tahun 2005 tentang Guru dan Dosen dalam Bab 1 Pasal 1 menjelaskan bahwa guru adalah pendidik profesional dengan tugas utama mendidik, mengajar, membimbing, mengarahkan, melatih, menilai, dan mengevaluasi peserta didik anak usia dini jalur pendidikan formal, pendidikan dasar, dan menengah.

Upaya pemerintah untuk meningkatkan mutu pendidik sebagai tenaga profesional salah satunya dengan memberikan Tunjangan Profesi Guru (TPG). Seperti yang telah disebutkan pada Harian Kompas (2017) pemerintah memberikan Tunjangan Profesi Guru (TPG) guna meningkatkan kualitas layanan pendidikan dan kesejahteraan guru sehingga mereka harus dapat meningkatkan kualitas dirinya sebagai guru.

Menurut Wahyudi (2012) guru profesional adalah guru yang mampu mengelola dirinya sendiri dalam melaksanakan tugastugasnya sehari-hari. Profesionalisme yang dimaksud oleh mereka adalah satu proses yang bergerak dari ketidaktahuan menjadi tahu, dari ketidakmatangan menjadi matang. Sedangkan menurut Glickman dalam Bafadal yang menegaskan bahwa seseorang akan bekerja secara 
profesioanl bilaman orang tersebut memiliki kemampuan profesional bilamana memiliki kemampuan tinggi dan motivasi kerja tinggi (Fitriani, 2017).

Profesionalisme guru menjadi perhatian secara global, karena guru memiliki tugas dan peran bukan hanya memberikan informasiinformasi ilmu pengetahuan dan teknologi, melainkan juga membentuk sikap dan jiwa yang mampu bertahan dalam era hiperkompetisi. Sudarwan Danim (2003:192) menegaskan bahwa tuntutan kehadiran guru yang profesional tidak pernah surut, karena dalam proses kemanusiaan dan pemanusiaan, ia hadir sebagai subjek paling diandalkan, yang sering kali disebut sebagai Oemar bakri. Guru sebagai pendidik profesional mempunyai citra yang baik di masyarakat apabila dapat menunjukkan kepada masyarakat bahwa layak menjadi panutan sekelilingnya, masyarakat terutama akan melihat sikap dan perbuatan guru itu sehari- hari. Untuk menciptakan seorang guru yang profesional dalam melahirkan dan meningkatkan kualitas sumber daya manusia perlu dijelaskan dalam paper ini dari sudut profesionalisme guru dalam meningkatkan kualitas sumber daya manusia (Yusutria, 2017).

Namun kenyataannya saat ini kualitas pendidikan di Indonesia masih tergolong rendah. Erdianto (2016) menyatakan berdasarkan survei program penilaian pelajar internasional atau PISA (Survei Programme International Student Assessment) yaitu penilaian tingkat dunia yang diselenggarakan tigatahunan menunjukkan peringkat pendidikan Indonesia tahun 2015 berada pada peringkat 64 dari 72 negara anggota Organization for Economic Cooperation and Development (OECD). Berdasarkan hasil survei tersebut, menunjukkan bahwa kualitas dan mutu pendidikan di Indonesia masih tergolong tertinggal dibandingkan dengan negara-negara lainnya di dunia.

Susanto (2014:165) menyatakan, "salah satu masalah penddikan yang dihadapi dunia pendidikan saat ini adalah lemahnya pelaksanaan proses pembelajaran yang diterapkan guru di sekolah". Lemahnya pelaksanaan proses pembelajaran terjadi hampir pada semua mata pelajaran, termasuk pada mata pelajaran IPA.

IPA merupakan salah satu mata pelajaran di sekolah dasar. Pembelajaran IPA umumnya memiliki peran penting dalam peningkatan mutu pendidikan. Khususnya di dalam menghasilkan peserta didik yang berkualitas, yaitu manusia yang mampu berpikir kritis, kreatif, logis, dan berinisiatif dalam menanggapi isu di masyarakat yang diakibatkan oleh dampak perkembangan sains dan teknologi. Pembelajaran sains bukan hanya menekankan pada banyaknya konsep-konsep sains yang dihafal, tetapi lebih kepada bagaimana agar siswa berlatih menemukan sendiri konsep-konsep itu dan secara kreatif dapat mengaitkan konsep-konsep itu ke dalam lingkungan sekitarnya.

Riastini (2016) menyatakan IPA atau sains memiliki tiga komponen yaitu sebagai proses, produk, dan sikap ilmiah. Kumpulan ilmu pengetahuan berupa fakta-fakta, konsep, prinsip, hukum, dan terori merupakan produk dari IPA. Proses IPA berkaitan dengan keterampilan-keterampilan/cara untuk memperoleh pengetahuan yang dikenal dengan metode ilmiah. Unsur lain adalah sikap ilmiah, merupakan sikap yang perlu dikembangkan dalam pembelajaran melalui kegiatan ilmiah, seperti diskusi, penyelidikan, simulasi, atau kegiatan proyek. Pengembangan sikap ilmiah sangat penting dalam kehidupan sehari-hari karena dapat membentuk pribadi manusia yang selalu menggunakan pertimbangan dalam mengambil keputusan. Sikap ilmiah yang dimiliki siswa juga akan mempengaruhi cara siswa dalam merespon objek, orang lain, atau peristiwa yang ada di sekitarnya. Namun kenyataan proses pembelajaran IPA di sekolah terkadang justru tidak seperti yang diharapkan.

Berdasarkan hasil observasi di kelas V di SD Gugus IV Kecamatan Buleleng pada tanggal 27 sampai 30 November 2017, proses pembelajaran IPA di sekolah lebih banyak menekankan pada produk IPA dibandingkan dengan proses IPA maupun sikap ilmiah. Pada proses pembelajaran yang dilakukan lebih menekankan pada kegiatan siswa mendengarkan penjelasan guru dan dilanjutkan dengan melatih siswa menjawab soal-soal IPA. Guru secara langsung memberikan definisi dari suatu kata serta memberikan prinsip dan konsep pembelajaran melalui kegiatan ceramah. Proses pembelajaran tersebut menunjukkan masih berpusat pada guru dan cenderung bersifat konvensional karena kegiatan proses pembelajaran yang sama dilaksanakan dengan berulang-ulang.

Proses pembelajaran yang menekankan kegiatan siswa mendengarkan secara terus-menerus akan mengundang rasa bosan. Hal tersebut terbukti pada pertengahan pembelajaran siswa mulai tidak memperhatikan penjelasan dari guru dan terlihat kurangnya sikap ilmiah siswa dalam proses pembelajaran. Kurangnya sikap ilmiah siswa ditunjukkan dari kurangnya keberanian siswa dalam mengungkapkan gagasan dan kurangnya rasa ingin tahu siswa terhadap materi pelajaran yang akan dipelajari. Hal tersebut terbukti dari jarangnya siswa memberikan respon terhadap penjelasan yang disampaikan oleh guru berkaitan dengan materi pembelajaran. Siswa juga cenderung pasif serta kurangnya keinginan siswa dalam mencari dan menemukan hal-hal baru yang berkaitan dengan materi yang dipelajari dengan membaca buku ataupun mencari sumber belajar lain yang dapat digunakan siswa sebagai bahan mencari informasi. 
Berdasarkan hasil wawancara, beberapa guru kelas V SD gugus IV Kabupaten Buleleng menyatakan bahwa dalam proses pembelajaran jarang menggunakan media pembelajaran karena keterbatasan sarana dan prasarana yang ada di sekolah. Hal ini mengakibatkan siswa berpikir abstrak dan berpengaruh terhadap kurangnya antusias siswa dalam mengikuti pembelajaran.

Pembelajaran akan lebih bermakna apabila siswa menemukan sendiri konsep yang dipelajari melalui proses ilmiah, karena kegiatan percobaan atau eksperimen menimbulkan dan mengembangkan sikap ilmiah pada siswa. Namun materi pembelajaran yang seharusnya dibelajarkan dengan percobaan tidak dilakukan, berdasarkan hasil wawancara hal ini dikarenakan keterbatasan sarana prasarana dan luasnya materi yang tidak sebanding dengan alokasi waktu sehingga tidak memungkinkan untuk melakukan percobaan karena dikhawatirkan materi selanjutnya tidak sempat dipelajari. Hal ini menunjukkan proses pembelajaran belum sesuai dengan hakikat IPA, dan mengakibatkan siswa hanya mengingat konsep-konsep yang disampaikan oleh guru serta berdasarkan hasil membaca siswa saja. Proses pembelajaran seperti demikian akan berpengaruh terhadap daya ingat siswa yang rendah dan berdampak pada hasil belajar siswa yang belum optimal.

Selain itu, berdasarkan hasil wawancara guru menyatakan jarang mengajak siswa untuk berdiskusi secara berkelompok. Hal tersebut mengakibatkan dalam proses pembelajaran kurangnya interaksi dan kerja sama untuk bertukar pikiran antarsiswa dalam pembelajaran. Berdasarkan beberapa permasalahan yang telah dipaparkan tersebut, mengakibatkan hasil belajar siswa masih banyak yang belum mencapai hasil Kriteria Ketuntasan Minimal (KKM).

Berdasarkan hasil pencatatan dokumen yang dilakukan yaitu tanggal 14 sampai 16 Desember 2017 pada mata pelajaran IPA, hasil belajar yang diperoleh siswa belum mencapai harapan. Hal ini tercermin dari nilai ulangan akhir semester siswa lebih banyak yang memperoleh nilai dibawah KKM, persentase ketuntasan hasil belajar IPA siswa hanya 40\%. Oleh karena itu, perlu upaya untuk pemecahan masalahmasalah tersebut.

Tentunya sebagai seorang guru harus bisa menciptakan proses pembelajaran yang menyenangkan agar dapat memotivasi siswa untuk aktif dalam proses pembelajaran sehingga mendapatkan hasil belajar yang optimal. Untuk mencapai hal tersebut salah satu caranya adalah dengan menerapkan model pembelajaran yang relevan, bervariasi dan sesuai dengan karakteristik materi yang akan dibelajarkan.

Pemilihan model yang sebaiknya diterapkan adalah model pembelajaran yang melibatkan peserta didik secara aktif serta mampu mengajak siswa untuk membangun pengetahuannya sendiri karena pengetahuan yang dibangun sendiri oleh siswa cenderung bersifat menetap atau tertanam pada memori otak jangka panjangnya. Kegiatan siswa yang secara langsung mengerjakan serta mengalaminya sendiri, akan mempermudah siswa dalam memahami suatu konsep. Sejalan dengan pernyataan Silberman (2009) pembelajaran yang semakin melibatkan aktivitas peserta didik secara aktif akan mampu meningkatkan daya ingat serta keterampilan peserta didik dalam memecahkan suatu permasalahan.

Salah satu model pembelajaran yang mempunyai karakteristik tersebut adalah model pembelajaran inquiry atau yang dalam bahasa Indonesianya inkuiri. Model pembelajaran inkuiri merupakan suatu kegiatan atau pelajaran yang dirancang sedemikian rupa sehingga siswa dapat menemukan konsep-konsep dan prinsip-prinsip melalui proses mentalnya sendiri (Suastra, 2009). Jenis model inkuiri yang paling cocok untuk diterapkan di sekolah dasar adalah model inkuiri terbimbing. Menurut Sadia (2014:131), "model inkuiri terbimbing pada umumnya digunakan bagi siswa yang belum memiliki pengalaman berinkuiri atau belum biasa belajar melalui inkuiri."

Pembentukan sikap ilmiah siswa akan lebih optimal apabila siswa melakukan proses penemuan melalui pengamatan secara langsung dengan objek pembelajaran yang dipelajari oleh siswa melalui media pembelajaran.

Media yang bisa membantu pemahaman siswa terhadap materi salah satunya adalah media benda konkret. Media benda konkret sangat sesuai dengan tingkat perkembangan anak sekolah dasar, yakni mereka lebih memahami konsep-konsep nyata daripada konsep-konsep abstrak. Hal ini sejalan dengan pendapat Piaget (dalam Danim, 2011) yang menyatakan bahwa anak sekolah dasar yakni kira-kira pada usia 7-11 tahun berada pada tahap operasional konkret, anak tidak dapat berpikir logis maupun abstrak, penalaran anak akan lebih mudah dengan hal-hal yang bersifat konkrit/nyata.

Berdasarkan hal tersebut, maka dilakukan penelitian untuk mengetahui pengaruh model pembelajaran inkuiri terbimbing berbantuan media benda konkret terhadap sikap ilmiah dan hasil belajar siswa. 


\section{Metode}

Penelitian ini menggunakan metode penelitian eksperimen. Adapun jenis eksperimen pada penelitian ini yaitu penelitian semu (quasi eksperiment).

Bentuk quasi experiment yang digunakan dalam penelitian ini adalah Nonequivalent Post Test Only Control Group Design yang terdiri dari kelompok kontrol dan kelompok eksperimen untuk dibandingkan. Desain ini digunakan karena eksperimen dilakukan di dalam kelas dengan siswa yang telah ada atau peneliti tidak mungkin mengubah kelas dalam menentukan subjek penelitian. Siswa kelompok kontrol yang dibelajarkan dengan pembelajaran yang secara rutin dilakukan oleh guru dijadikan sebagai pembanding untuk mengetahui pengaruh penerapan model pembelajaran inkuiri terbimbing berbantuan media benda konkret terhadap sikap ilmiah dan hasil belajar pada siswa kelompok eksperimen. Kedua kelompok siswa dipilih secara random sehingga dapat ditarik kesimpulan penelitian. Populasi dalam penelitian ini adalah semua siswa kelas V SD Gugus IV Kecamatan Buleleng tahun pelajaran 2017/2018 yakni sebanyak 155 orang.

Sampel dalam penelitian ini ditentukan dengan menggunakan teknik random sampling. Sebelum menetapkan sampel penelitian, populasi diuji kesetarannya berdasarkan nilai UAS IPA siswa pada semester ganjil dengan uji Anava satu jalur.

Berdasarkan hasil uji kesetaraan yang telah dilakukan didapatkan hasil bahwa seluruh siswa kelas IV SD Negeri Gugus IV Kecamatan Buleleng memiliki kemampuan yang setara. Kemudian dilakukan pengundian dengan teknik random sampling untuk mengambil dua kelas yang akan dijadikan subjek penelitian. Dari dua kelas tersebut, diundi kembali untuk menentukan kelas yang akan menjadi kelompok eksperimen dan kelas yang akan menjadi kelompok kontrol. Melalui teknik tersebut, diperoleh SD Negeri 3 Penglatan dengan jumlah 23 orang siswa menjadi kelompok eksperimen dan SD Negeri 3 Alasangker dengan jumlah 20 orang siswa menjadi kelompok kontrol.

Data pada penelitian ini ada dua yaitu sikap ilmiah dan hasil belajar IPA siswa. Data mengenai sikap ilmiah siswa dikumpulkan menggunakan lembar kuisioner menggunakan skala likert dengan alternatif jawaban berkisar 1 sampai 5. Sedangkan data mengenai hasil belajar IPA siswa dikumpulkan mengunakan instrumen tes objektif pilihan ganda dengan empat pilihan.

Pembuatan instrumen dalam penelitian ini terlebih dahulu dilakukan dengan menyusun kisi-kisi intrumen. Kisi-kisi hasil belajar disusun denga berpedoman pada kurikulum KTSP 2006 menyangkut standar kompetensi, kompetensi dasar, aspek materi, dan indikatornya. Sebelum instrumen digunakan, terlebih dahulu dilakukan expert judgment oleh dua orang pakar agar mendapatkan kualitas tes yang baik. Setelah dilakukan expert judgment, selanjutnya instrumen diujicobakan ke lapangan. Data yang diperoleh hasil uji coba dianalisis dengan uji konsistensi internal butir, uji reliabilitas tes, uji tingkat kesukaran butir tes, uji daya beda butir tes, dan uji efektivitas pengecoh.

Berdasarkan hasil perhitungan diperoleh 33 butir pernyataan sikap ilmiah yang valid dan hasil uji reliabitas sebesar 0,897 yaitu kategori reliabilitas sangat tinggi. Untuk hasil belajar IPA, berdasarkan hasil perhitungan diperoleh 32 soal yang valid dengan reliabilitas sebesar 0,90 yaitu kategori reliabilitas sangat tinggi, tingkat kesukaran tes sebesar 0,36 yang berada pada kategori sedang, daya beda 0,55 berada pada kategori baik.

Hasil penelitian ini dianalisis secara bertahap, yaitu: deskripsi data, uji prasyarat analisis, dan uji hipotesis. Uji prasyarat analisis yaitu uji normalitas sebaran data, uji homogenitas varian, uji korelasi antar-variabel terikat.

\section{Hasil dan Pembahasan}

Data hasil perhitungan yang dianalisis adalah data dalam bentuk skor. Data sikap ilmiah dan hasil belajar IPA siswa didapatkan dari hasil posttest. Jumlah butir pernyataan pada kuisioner sikap ilmiah adalah 30 butir dan sebanyak 30 butir soal pilihan ganda pada tes hasil belajar IPA.

Selama kegiatan post test, siswa kelas eksperimen dan kelas kontrol hadir secara keseluruhan. Jumlah pertemuan pada masing-masing kelas eksperimen dan kelas kontrol adalah sebanyak 7 kali pertemuan dan ditambah 1 kali pertemuan untuk pemberian post test.

Data yang diperoleh dalam penelitian ini terdiri atas empat kelompok distribusi yaitu: (1) Sikap ilmiah siswa yang mengikuti model pembelajaran inkuiri terbimbing berbantuan media benda konkret (A1Y1), (2) Sikap Ilmiah siswa yang mengikuti pembelajaran konvensional (A2Y1), (3) Hasil belajar siswa yang mengikuti model pembelajaran inkuiri terbimbing berbantuan media benda konkret (A1Y2), dan (4) Hasil belajar siswa yang mengikuti pembelajaran konvensional (A2Y2). Deskripsi data secara umum disajikan pada Tabel 1 sebagai berikut. 
Tabel 1. Rekapitulasi Hasil Perhitungan Skor Sikap ilmiah dan Hasil Belajar Kelompok Eksperimen dan Kelompok Kontrol

\begin{tabular}{lllll}
\hline \multicolumn{1}{c}{ Data } & A1Y1 & A2Y1 & A1Y2 & A2Y2 \\
\hline Statistik & & & 23 & 20 \\
\multicolumn{1}{c}{ Jumlah responden } & 23 & 20 & 24,43 & 21,25 \\
Mean (X) & 129,61 & 114,15 & 25 & 19 \\
Median & 130,5 & 113,51 & 26 & 2,83 \\
Modus & 135 & 113,16 & 2,54 & 7,99 \\
Standar Deviasi (SD) & 8,71 & 11,19 & 6,44 & 17 \\
Varians (S') & 75,86 & 125,29 & 19 & 26 \\
Skor Minimum $\left(X_{\text {min }}\right)$ & 110 & 97 & 28 & 10 \\
Skor Maksimum $\left(X_{\text {maks }}\right)$ & 143 & 136 & 10 & \\
Jangkauan/rentangan & 34 & 40 & & \\
\hline
\end{tabular}

Berdasarkan Tabel 1, diketahui bahwa rata-rata skor sikap ilmiah yang diperoleh oleh kelompok siswa mengikuti model pembelajaran inkuiri terbimbing berbantuan media benda konkret (A1YI) adalah 129,61 berada pada kategori sangat tinggi dan rata-rata skor sikap ilmiah yang diperoleh oleh kelompok siswa yang mengikuti pembelajaran konvensional (A2Y1) adalah 114,15. Dengan demikian, secara deskriptif dapat dijelaskan bahwa sikap ilmiah siswa yang mengikuti pembelajaran dengan model pembelajaran inkuiri terbimbing berbantuan media benda konkret (A1Y1) lebih baik dibandingkan dengan siswa yang mengikuti pembelajaran konvensional (A2Y1).

Rata-rata skor hasil belajar IPA yang diperoleh oleh kelompok siswa mengikuti model pembelajaran inkuiri terbimbing berbantuan media benda konkret (A1Y2) adalah 24,43 dan rata-rata skor hasil belajar IPA yang diperoleh oleh kelompok siswa yang mengikuti pembelajaran konvensional (A2Y2) adalah 21,25. Dengan demikian, secara deskriptif dapat dijelaskan bahwa hasil belajar IPA siswa yang mengikuti pembelajaran dengan model pembelajaran inkuiri terbimbing berbantuan media benda konkret (A1Y2) lebih baik dibandingkan dengan siswa yang mengikuti pembelajaran konvensional (A2Y2).

Berdasarkan uraian deskripsi data sikap ilmiah dan hasil belajar IPA pada kelompok eksperimen dan kelompok kontrol dapat ditentukan kualitas tinggi rendahnya kualitas variabel tersebut. Untuk menentukan tinggi rendahnya kualitas variabel maka skor rata-rata (mean) tiap-tiap variabel dikonversikan dengan menggunakan kriteria rata-rata ideal $\left(\mathrm{M}_{\mathrm{i}}\right)$ dan standar deviasi ideal $\left(\mathrm{SD}_{\mathrm{I}}\right)$. Sebelum dimasukkan ke dalam konversi skala lima, terlebih dahulu dihitung rata-rata skor (mean) dan standar deviasi (SD).

Adapun kategori penentuan tinggi rendanya sikap ilmiah siswa kelompok eksperimen dan kelompok kontrol dengan kualifikasi menggunakan pedoman konversi skala lima dapat disajikan pada Tabel 2 berikut.

Tabel 2. Kategori Data Sikap ilmiah Kelompok Kontrol dan Kelompok Eksperimen

\begin{tabular}{cc}
\hline Rentangan Skor & Kategori \\
\hline $120 \leq \overline{\mathrm{X}} \leq 150$ & Sangat Tinggi \\
$100 \leq \overline{\mathrm{X}}<120$ & Tinggi \\
$80 \leq \overline{\mathrm{X}}<100$ & Sedang \\
$60 \leq \overline{\mathrm{X}}<80$ & Rendah \\
$30 \leq \bar{X}<60$ & Sangat Rendah \\
\hline
\end{tabular}

Nilai rata-rata sikap ilmiah siswa pada kelompok eksperimen adalah 129,61. Berdasarkan tabel 2 rata-rata skor sikap ilmiah siswa pada kelompok eksperimen terletak pada pada rentangan $120 \leq \bar{X} \leq 150$ yaitu berada pada kategori sangat tinggi. Sedangkan rata-rata skor sikap ilmiah pada kelompok kontrol adalah 114,15. Berdasarkan tabel 2 rata-rata skor sikap ilmiah siswa pada kelompok kontrol terletak pada rentangan $100 \leq \bar{X}<120$ yaitu berada pada kategori tinggi.

Tabel untuk menentukan kategori data hasil belajar IPA kelompok eksperimen dan kontrol disajikan pada Tabel 3 berikut. 
Tabel 3. Kategori Data Hasil Belajar IPA

\begin{tabular}{cc}
\hline Rentangan Skor & Kategori \\
\hline $22,5 \leq \overline{\mathrm{X}} \leq 30$ & Sangat Tinggi \\
\hline $17,5 \leq \overline{\mathrm{X}}<22,5$ & Tinggi \\
\hline $12,5 \leq \overline{\mathrm{X}}<17,5$ & Sedang \\
\hline $7,5 \leq \overline{\mathrm{X}}<12,5$ & Rendah \\
\hline $0 \leq \bar{X}<7,5$ & Sangat Rendah \\
\hline
\end{tabular}

Nilai rata-rata hasil belajar IPA siswa pada kelompok eksperimen adalah 24,43. Berdasarkan tabel 2 rata-rata skor hasil belajar IPA siswa pada kelompok eksperimen terletak pada pada rentangan $22,5 \leq \bar{X} \leq 30$ yaitu berada pada kategori sangat tinggi. Sedangkan rata-rata skor hasil belajar IPA pada kelompok kontrol adalah 21,25. Berdasarkan tabel 2 rata-rata skor hasil belajar IPA siswa pada kelompok kontrol terletak pada rentangan $17,5 \leq \bar{X}<22,5$ yaitu berada pada kategori tinggi.

Sebelum dilakukan pengujian hipotesis, terlebih dahulu dilakukan uji prasyarat analisis yaitu uji normalitas sebaran data, uji homogenitas varian, dan uji korelasi antar variabel terikat.

Berdasarkan hasil uji normalitas sebaran data menggunakan rumus chi-kuadrat menunjukkan keempat kelompok data memperoleh $\chi^{2}{ }_{\text {hitung }}<\chi^{2}$ tabel sehingga semua sebaran data dinyatakan berdistribusi normal.

Selanjutnya uji homogenitas dilakukan data sikap ilmiah dan hasil belajar secara terpisah dan bersama-sama. Uji homogenitas secara terpisah dilakukan dengan Uji F. Berdasarkan uji F diperoleh $F_{\text {hitung }}$ sikap ilmiah sebesar 1,65 dan $F_{\text {hitung }}$ hasil belajar sebesar 1,24. Sedangkan $F_{\text {tabel }}$ adalah 4,08. Ini menunjukkan $F_{\text {hitung }}<F_{\text {tabel }}$, hal ini berarti data sikap ilmiah maupun data hasil belajar IPA siswa adalah homogen. Sedangkan uji homogenitas varian secara bersama-sama dapat dilihat dari hasil uji Box's $M$, yaitu menunjukkan hasil signifikansi lebih dari 0,05. Berdasarkan hasil tersebut dapat disimpukan bahwa hasil uji homogenitas varian secara bersama-sama menunjukkan bahwa matriks varian-kovarians terhadap sikap ilmiah dan hasil belajar IPA siswa homogen.

Uji prasyarat ketiga yaitu uji korelasi antar variabel terikat. Hasil uji korelasi variabel terikat data sikap ilmiah dan hasil belajar IPA siswa yang mengikuti model pembeljaran inkuiiri terbimbing berbantuan media benda konkret memiliki harga $r_{\text {hitung }}=0,32<r_{\text {tabel }}=0,413$, sedangkan data sikap ilmiah dan hasil belajar IPA siswa yang mengikuti pembelajaran konvensional adalah $r_{\text {hitung }}=0,37<r_{\text {tabel }}=0,444$ pada taraf signifikansi 5\%, sehingga dapat ditarik kesimpulan bahwa data sikap ilmiah dan hasil belajar IPA yang mengikuti model pembelajaran inkuiri terbimbing berbantuan media benda konkret maupun pembelajaran konvensional tidak berkorelasi signifikan.

Untuk pembuktian hipotesis pertama dan kedua yang diajukan dilakukan dengan pengujian menggunakan uji anava satu jalur, sedangkan pengujian hipotesis ketiga menggunakan uji Manova. Hasil uji anava untuk hipotesis pertama dapat dilihat pada Tabel 4 berikut.

Tabel 4. Hasil Analisis Uji Hipotesis I Data Sikap Ilmiah Siswa

\begin{tabular}{|c|c|c|c|c|c|c|c|}
\hline \multirow{2}{*}{ Sumber } & \multirow{2}{*}{ JK } & \multirow{2}{*}{ Db } & \multirow{2}{*}{ RJK } & \multirow{2}{*}{$\mathbf{F}_{\text {hitung }}$} & \multicolumn{2}{|c|}{$\mathbf{F}_{\text {tabel }}$} & \multirow{2}{*}{ Keputusan } \\
\hline & & & & & $5 \%$ & $1 \%$ & \\
\hline Antar & 2556,43 & 1 & 2556,44 & 25,88 & 4,08 & 7,31 & Signifikan \\
\hline Dalam & 4050,04 & 41 & 98,78 & & & & \\
\hline Total & 6606,47 & - & - & & & & \\
\hline
\end{tabular}

Berdasarkan Tabel 4. dapat diketahui bahwa sikap ilmiah siswa yang mengikuti pembelajaran inkuiri terbimbing berbantuan media benda konkret dan pembelajaran konvensional menunjukkan harga $\mathrm{F}_{\text {hitung }}=25,88>\mathrm{F}_{\text {tabel }}=4,08$ pada taraf signifikansi 5\%. Hal ini berarti dapat disimpulkan $\mathrm{H}_{\mathrm{o}}$ ditolak dan $\mathrm{H}_{\mathrm{a}}$ diterima. Sehingga terdapat perbedaan yang signifikan sikap ilmiah anatar siswa yang mengikuti model 
pembelajaran inkuiri terbimbing berbantuan media benda konkret dengan kelompok siswa yang mengikuti pembelajaran konvensional pada siswa kelas V SD Gugus IV Kecamatan Buleleng tahun pelajaran 2017/2018.

Tabel 5. Hasil Analisis Uji Hipotesis II Data Hasil Belajar IPA Siswa

\begin{tabular}{llllllll}
\hline \multirow{2}{*}{ Sumber } & \multirow{2}{*}{ JK } & Db & \multirow{2}{*}{$\mathbf{R J K}$} & $\mathbf{F}_{\text {hitung }}$ & $\mathbf{F}_{\text {tabel }}$ & & \multirow{2}{*}{ Keputusan } \\
\hline Antar & 108,51 & 1 & 108,51 & 15,16 & 4,08 & 7,31 & Signifikan \\
\hline Dalam & 293,41 & 41 & 7,15 & & & & \\
\hline Total & 401,91 & - & - & & & & \\
\hline
\end{tabular}

Berdasarkan Tabel 5. dapat diketahui bahwa hasil belajar IPA siswa yang mengikuti pembelajaran inkuiri terbimbing berbantuan media benda konkret dan pembelajaran konvensional menunjukkan harga $F_{\text {hitung }}=15,16>F_{\text {tabel }}=4,08$ pada taraf signifikansi $5 \%$. Hal ini berarti dapat disimpulkan $\mathrm{H}_{0}$ ditolak dan $\mathrm{H}_{\mathrm{a}}$ diterima. Sehingga terdapat perbedaan yang signifikan hasil belajar IPA siswa yang mengikuti model pembelajaran inkuiri terbimbing berbantuan media benda konkret dengan kelompok siswa yang mengikuti pembelajaran konvensional pada siswa kelas V SD Gugus IV Kecamatan Buleleng tahun pelajaran 2017/2018.

Analisis hipotesis ketiga dilakukan dengan menggunakan uji Manova. Hasil analisis uji hipotesis ketiga dengan uji Manova disajiikan pada Tabel 6 berikut

Tabel 6. Hasil Analisis Uji Hipotesis III menggunakan SPSS Statistik 17.0 for windows

\begin{tabular}{|c|c|c|c|c|c|c|}
\hline \multicolumn{7}{|c|}{ Multivariate Testsb } \\
\hline Effect & & Value & $\mathrm{F}$ & Hypothesis df & Error df & Sig. \\
\hline \multirow[t]{4}{*}{ Intercept } & Pillai's Trace & .994 & $3568.680^{a}$ & 2.000 & 40.000 & .000 \\
\hline & Wilks' Lambda & .006 & $3568.680^{\mathrm{a}}$ & 2.000 & 40.000 & .000 \\
\hline & Hotelling's Trace & 178.434 & $3568.680^{\mathrm{a}}$ & 2.000 & 40.000 & .000 \\
\hline & Roy's Largest Root & 178.434 & $3568.680^{a}$ & 2.000 & 40.000 & .000 \\
\hline \multirow[t]{4}{*}{$\mathrm{K}$} & Pillai's Trace & .430 & $15.111^{\mathrm{a}}$ & 2.000 & 40.000 & .000 \\
\hline & Wilks' Lambda & .570 & $15.111^{\mathrm{a}}$ & 2.000 & 40.000 & .000 \\
\hline & Hotelling's Trace & .756 & $15.111^{\mathrm{a}}$ & 2.000 & 40.000 & .000 \\
\hline & Roy's Largest Root & .756 & $15.111^{\mathrm{a}}$ & 2.000 & 40.000 & .000 \\
\hline
\end{tabular}

a. Exact statistic

b. Design: Intercept $+\mathrm{K}$

Berdasarkan tabel Multivariate Test yaitu bagian K, hasil analisis menunjukkan bahwa Pillai's Trace, Wilks' Lamba, Hotelling's Trace, Roy's Largest Root memiliki nilai F= 15,111 dan nilai signifikansi yang lebih kecil dari 0,05. Artinya harga F untuk Pillai's Trace, Wilks' Lamba, Hotelling's Trace, Roy's Largest Root semuanya signifikan. Jadi dapat disimpulkan $\mathrm{H}_{\mathrm{o}}$ ditolak dan $\mathrm{H}_{\mathrm{a}}$ diterima yaitu secara bersama-sama atau simultan terdapat perbedaan yang signifikan sikap ilmiah dan hasil belajar IPA siswa kelas V SD Gugus IV Kecamatan Buleleng antara siswa yang mengikuti model pembelajaran inkuiri terbimbing berbantuan media benda konkret dengan siswa yang mengikuti pembelajaran konvensional pada siswa kelas V SD Gugus IV Kecamatan Buleleng tahun pelajaran 2017/2018.

Hasil analisis uji hipotesis pertama menunjukkan bahwa sikap ilmiah dengan model pembelajaran inkuiri terbimbing berbantuan media benda konkret lebih baik dari pembelajaran konvensional. Hal ini disebabkan karena pada tahapan pembelajaran dengan model inkuiri terbimbing siswa diberikan kesempatan untuk terlibat lebih aktif dalam proses pembelajaran. Keterlibatan siswa secara aktif baik secara fisik maupun mental dalam kegiatan pembelajaran akan membawa pengaruh terhadap pola tindakan siswa yang selalu didasarkan pada hal-hal yang bersifat ilmiah.

Tahapan pembelajaran dengan model pembelajaran inkuiri terbimbing menurut Suastra (2009) terdiri atas lima fase pertama yaitu elisitasi gagasan awal siswa, fase kedua yaitu pengujian gagasan awal, fase ketiga yaitu negosiasi makna, fase keempat yaitu penerapan konsep pada situasi baru, dan fase kelima yaitu pembuatan kesimpulan dan refleksi. Adapun temuan yang diperoleh di lapangan pada 
pelaksanaan model inkuiri terbimbing sesuai dengan tahapan pembelajaran inkuiri tersebut yaitu sebagai berikut.

Fase pertama pada pembelajaran inkuiri terbimbing yaitu elisitasi gagasan awal siswa, pada tahapan ini guru memfasilitasi siswa untuk menggali gagasan awal siswa dengan mengajukan pertanyaan atau masalah yang berkaitan dengan topik yang akan dibicarakan. Pada tahapan ini guru membangkitkan rasa ingin tahu siswa, sehingga memunculkan rasa antusias siswa dalam mengikuti proses pembelajaran. Kegiatan siswa pada tahapan ini yaitu membuat hipotesis terkait dengan masalah yang diajukan. Kegiatan ini dapat mengembangkan sikap berpikir kritis pada siswa karena siswa belajar mengemukakan jawaban sementaranya berdasarkan pengetahuan awal siswa.

Pada fase kedua yaitu fase pengujian gagasan awal siswa. Pada tahapan ini siswa melakukan kegiatan pengujian terhadap hipotesis yang diajukan dengan dipandu LKS. Kegiatan pada fase kedua ini dilakukan siswa bersama teman kelompoknya, hal ini dapat mengembangkan sikap terbuka dan kerja sama pada siswa. Penggunaan media konkret dalam tahapan ini dapat mengembangkan dimensi sikap ingin tahu, yakni meningkatkan antusias siswa ketika melakukan kegiatan penemuan atau percobaan yang dilakukan. Hal ini sejalan dengan pendapat Kusumayanti (2013) menjelaskan "media konkret sangat membantu dalam proses pembelajaran yaitu dapat membangkitkan motivasi dan merangsang siswa untuk belajar".

Pada fase ketiga yaitu negosiasi makna. Kegiatan ini memunculkan sikap penemuan dan kreativitas yaitu siswa melakukan diskusi kelas terkait hasil penyelidikan dan kemudian menunjukkan penemuannya dengan cara menyajikan hasil diskusi yang dilakukan secara berkelompok di depan kelas. Siswa belajar menanggapi hasil penyajian yang dilakukan dari kelompok penyaji sehingga mengembangkan sikap berpikir terbuka yakni siswa diajarkan untuk menghargai pendapat/temuan orang lain dan belajar mau merubah pendapat apabila data yang dimiliki kurang.

Pada fase keempat yaitu penerapan konsep pada situasi baru, kegiatan yang dilakukan pada tahapan ini yaitu siswa memperbaiki konsep yang masih menyimpang setelah guru memberikan konfirmasi atas konsep-konsep siswa yang masih menyimpang. Pada tahapan ini memunculkan sikap berpikir terbuka, yaitu siswa belajar untuk merubah pendapat ababila data yang dimiliki masih kurang. Pada fase ini, siswa menerapkan konsep-konsep yang dimilikinya pada situasi baru misalnya dengan latihan soal, pemecahan masalah, dan lain-lain.

Pada fase kelima yaitu fase pembuatan kesimpulan dan refleksi. Tahapan ini dapat memunculkan sikap berpikir kritis, yaitu siswa belajar tidak mengabaikan data sekecil apapun dalam menarik sebuah kesimpulan.

Pelaksanaan pembelajaran menggunakan model inkuiri terbimbing berbantuan media benda konkret dapat mendorong siswa agar mengembangkan sikap peka terhadap lingkungan. Dalam proses percobaan yang dilakukan siswa menggunakan media benda konkret, pada proses ini guru mendapatkan kesempatan untuk mendorong siswa menjaga kebersihan lingkungan dan diajarkan untuk bekerja dengan rapi.

Hasil analisis hipotesis kedua menyatakan hasil belajar IPA siswa yang mengikuti pembelajaran inkuiri terbimbing berbantuan media benda konkret lebih baik dari pembelajaran konvensional. Hal ini dikarenakan pada proses pembelajaran inkuiri terbimbing siswa diberikan peluang untuk terlibat aktif dalam pembelajaran dengan melakukan percobaan untuk menemukan suatu konsep yang dipelajari.

Santiasih (2013) bahwa model pembelajaran inkuiri terbimbing mengarahkan anak agar dapat menemukan pengetahuannya melalui proses ilmiah. Konsep yang ditemukan sendiri tersebut akan lebih diingat oleh siswa. Sejalan dengan pendapat Piaget (dalam Sanjaya, 2007:196) menyatakan "pengetahuan akan bermakna apabila dicari dan ditemukan sendiri oleh siswa". Pengetahuan yang dibangun sendiri tersebut cenderung bersifat menetap karena siswa sendiri yang mengalaminya, sehingga dapat berdapak positif terhadap hasil belajar siswa.

Hasil hipotesis ketiga menunjukkan bahwa sikap ilmiah dan hasil belajar IPA siswa yang mengikuti pembelajaran inkuiri terbimbing berbantuan media benda konkret lebih baik dari pembelajaran konvensional. Model pembelajaran yang mampu mengajak siswa untuk membangun pengetahuannya sendiri cenderung meningkatkan daya ingat siswa, karena siswa langsung mengerjakan dan mengalaminya sendiri. Daya ingat yang tinggi akan berpengaruh terhadap skor hasil belajar yang diperoleh oleh siswa.

Model pembelajaran inkuiri terbimbing merupakan model pembelajaran yang mengajak siswa untuk menemukan sendiri konsep yang dipelajarinya. Pada pembelajaran dengan menggunakan model ini, siswa lebih mudah memahami pelajaran karena melibatkan siswa secara langsung dengan pengalaman-pengalaman seperti menyentuh, mempraktikkan, dan melakukan percobaan. Pembelajaran seperti demikian lebih bermakna bagi siswa dan berdampak terhadap hasil belajar IPA yang lebih baik. 
Tahapan pembelajaran model pembelajaran inkuiri terbimbing berbantuan media benda konkret mengembangkan sikap-sikap ilmiah. Siswa terlihat antusias dalam mengikuti pembelajaran, menunjukkan sikap respek terhadap data serta sikap penemuan dan kreativitas pada saat melakukan pelakukan pengujian terhadap hipotesis, belajar berpikir terbuka dan kerja sama dalam diskusi, berpikir kritis untuk menganalisis temuan yang diperoleh, serta didorongnya siswa agar peka terhadap lingkungan selama proses pembelajaran berlangsung. Pembelajaran ini menunjukkan dapat mengembangkan sikap ilmiah siswa. Dengan demikian pemahaman dan ingatan siswa terhadap suatu konsep IPA menjadi kuat dan bertahan lama. Hal ini akan memberikan pengaruh positif terhadap sikap ilmiah dan hasil belajar siswa.

Hasil penelitian ini didukung pula oleh penelitian yang pernah dilakukan oleh Santiasih (2013) yang menunjukkan bahwa sikap ilmiah dan hasil belajar IPA dengan menggunakan model pembelajaran inkuiri terbimbing lebih baik dari model pembelajaran konvensional. Selanjutnya, penelitian yang dilakukan Susanti (2014) menunjukkan penerapan model Snow Ball Throwing berbantuan media benda konkret berpengaruh terhadap hasil belajar IPA.

Hal ini dipertegas dengan penjelasan (2014) bahwa keterlibatan siswa dalam kegiatan inkuiri memberi kesempatan pada siswa untuk memupuk rasa tanggung jawab, mengembangkan aktivitas, memupuk kejujuran, menumbuhkan rasa ingin tahu, danmenumbuhkan rasa percaya diri, dan pada ujungnya akan berdampak positif terhadap pencapaian hasil belajar yang lebih baik.

Berdasarkan pemaparan tersebut, dapat dinyatakan bahwa model pembelajaran inkuiri terbimbing berbantuan media benda konkret pengaruh signifikan terhadap sikap ilmiah dan hasil belajar IPA siswa Kelas V SD Gugus IV Kecamatan Buleleng tahun pelajara 2017/2018.

\section{Simpulan dan Saran}

Berdasarkan Hasil penelitian dan pembahasan, dapat disimpulkan hal-hal sebagai berikut. Pertama, terdapat pengaruh yang signifikan model pembelajaran inkuiri terbimbing berbantuan media benda konkret terhadap sikap ilmiah siswa. Kedua, terdapat pengaruh yang signifikan model pembelajaran inkuiri terbimbing berbantuan media benda konkret terhadap hasil belajar IPA siswa. Ketiga, secara simultan terdapat pengaruh yang signifikan model pembelajaran inkuiri terbimbing berbantuan media benda konkret terhadap sikap ilmiah dan hasil belajar IPA siswa.

Berdasarkan hasil penelitian, maka dapat diajukan brberapa saran untuk meningkatkan kualitas pembelajaran kedepannya. Guru sebagai penyelenggara pembelajaran, hendaknya menggunakan model pembelajaran yang inovatif, sesuai dengan karakteristik siswa dan materi, serta mengajak siswa untuk terlibat aktif dalam pembelajaran. Salah satu model pembelajaran yang bisa digunakan adalah model pembelajaran inkuiri terbimbing berbantuan media benda konkret yang dapat meningkatkan sikap ilmiah dan hasil belajar IPA siswa. Untuk lebih mengoptimalkan hasil dari pelaksanaan pembelajaran dengan model pembelajaran inkuiri terbimbing berbantuan media benda konkret, hendaknya guru lebih mendalami sintak-sintak pelaksanaan dari model pembelajaran tersebut agar penerapannya dapat berlangsung dengan baik sehingga dapat meningkatkan sikap ilmiah maupun hasil belajar siswa.

Disarankan kepada peneliti lain yang berniat melaksanakan penelitian sejenis dalam bidang ilmu pengetahuan alam maupun bidang ilmu lainnya, diharapkan agar bisa mengembangkan lagi penelitian ini dengan melibatkan sampel yang lebih luas, melakukan penelitian dengan materi pembelajaran yang berbeda dan waktu yang lebih lama agar mendapatkan gambaran yang lebih tepat mengenai model pembelajaran inkuiri terbimbing berbantuan media benda konkret terhadap sikap ilmiah dan hasil belajar IPA siswa.

\section{Daftar Rujukan}

Danim, Sudarwan. 2011. Perkembangan Peserta Didik. Bandung: Alfa Beta.

Depdiknas. 2003. Undang-undang Republik Indonesia Nomor 20 Tahun 2003 tentang Sistem Pendidikan Nasional. 2003. Jakarta: Depdiknas.

Depdiknas. 2005. Peraturan Pemerintah Republik Indonesia Nomor 14 Tahun 2005 tentang Guru dan Dosen. Jakarta: Depdiknas.

Erdianto, Kristian. 2018. Komnas HAM Catat 4 Kondisi Darurat Pendidikan Indonesia. Tersedia pada: https://nasional.kompas.com/read/2018/05/02/12581141/komnas-ham-catat-4-kondisidarurat-pendidikan-indonesia (diakses tanggal 14 Juli 2018). 
Fitriani, Cut. 2015. Kompetensi Profesional Guru Dalam Pengelolaan Pembelajaran Di Mts Muhammadiyah Banda Aceh . Jurnal Magister Administrasi Pendidikan ISSN 2302-0156

Kompas. 2017. Program Sertifikasi dan Tunjangan Profesi Guru Tetap Ada. Terdapat pada http://edukasi.kompas.com/read/2017/08/16/19390071/program-sertifikasi-dantunjanganprofesi-guru-tetap-ada. Diakses tanggal 13 Desember 2017.

Munirah. 2015. Sistem Pendidikan Di Indonesia: Antara Keinginan Dan Realita . Jurnal Auladuna, Vol. 2 No. 2 Desember 2015: 233-245

Riastini, Putu Nanci. 2016. Pembelajaran IPA SD. Singaraja: Unit Penerbitan Universitas Pendidikan Ganesha.

Sadia, I Wayan. 2014. Model-model Pembelajaran Sains Konstruktivistik. Yogyakarta: Graha Ilmu. Sanjaya, Wina. 2007. Strategi Pembelajaran Berorientasi Standar Proses Pendidikan. Jakarta: Kencana Prenada Media Group.

Saat, Sulaiman . 2015. Faktor-Faktor Determinan Dalam Pendidikan (Studi Tentang Makna Dan Kedudukannya Dalam Pendidikan . Jurnal Al-Ta'dib Vol. 8 No. 2, Juli-Desember 2015.

Santiasih. 2013. "Pengaruh Model Pembelajaran Inkuiri terbimbing terhadap Sikap Ilmiah dan Hasil Belajar IPA Siswa Kelas V SD No.1 Kerobokan Kecamatan Kuta Utara Kabupaten Badung Tahun Pelajaran 2013/2014". e-Journal Program Pascasarjana Universitas Pendidikan Ganesha Program Studi Pendidikan Dasar. Volume 3. Diakses tanggal 18 mei 2018.

Silberman, Mel. 2009. Active Larning 101 Strategi Pembelajaran Aktif. Yogyakarta: Pustaka Insan Madani.

Suastra, I Wayan. 2009. Pembelajaran Sains Terkini. Singaraja: Universitas Pendidikan Ganesha.

Susanti, Ayu. 2014. "Pengaruh Model Snowball Throwing Berbantuan Media Konkret terhadap Hasil Belajar IPA Siswa Kelas V SD Gugus i Ngurah Rai Denpasar". E-Journal Mimbar PGSD Undiksha. Volume 2, Nomor 1.

Susanto, Ahmad. 2014. Teori Belajar \& Pembelajaran di Sekolah Dasar. Jakarta: Kencana Prenadamedia Group.

Yusutria .2017. Rofesionalisme Guru Dalam Meningkatkan Kualitas Sumberdaya Manusia . Jurnal Curricula Kopertis Wilayah X Vol 2, No. 12017 